\title{
HUBUNGAN MAKANAN DAN KEBIASAAN CUCI TANGAN DENGAN KEJADIAN DIARE PADA ANAK USIA DINI DI KELURAHAN TAMBAK WEDI KECAMATAN KENJERAN SURABAYA
}

\author{
RUKMINI \\ AKADEMI KEPERAWATAN ADI HUSADA SURABAYA \\ ifaariqnaura@gmail.com
}

\begin{abstract}
ABSTRAK
Makanan yang sehat mengandung zat gizi yang dibutuhkan anak-anak. Namun kontaminasi bakteri dan racun mengakibatkan diare. Kebiasaan cuci tangan yang tidak benar juga meningkatkan angka kejadian diare. Tujuan dari penelitian ini adalah mengidentifikasi hubungan makanan dan kebiasaan cuci tangan dengan kejadian diare pada anak usia dini di Kelurahan Tambak Wedi Kecamatan Kenjeran, Surabaya. Penelitian ini menggunakan desain korelasi dengan pendekatan cross sectional. Sampel dari penelitian ini adalah 67 anak pada lima PAUD di Kelurahan Tambak Wedi Kecamatan Kenjeran. Teknik sampling yang digunakan adalah simple random sampling. Data diperoleh menggunakan kuesioner. Hasil kemudian ditabulasi dan diuji menggunakan koefisien kontigensi. Hasil uji koefisien kontigensi didapatkan hasil antara makanan dan kejadian diare dimana p value $0.000(\alpha \leq 0.05)$ dan $r=0.615$ sehingga terdapat hubungan kuat antara makanan dan kejadian diare. Hasil uji koefisien kontigensi didapatkan hasil antara makanan dan kejadian diare dimana $\mathrm{p}$ value $0.000(\alpha \leq 0.05)$ dan $\mathrm{r}=0.619$, sehingga terdapat hubungan kuat antara kebiasaan mencuci tangan dengan kejadian diare. Diharapkan orang tua dapat menyediakan makanan yang sehat dan membiasakan cuci tangan yang benar sejak usia dini pada anak agar dapat mencegah kejadian diare.
\end{abstract}

Kata kunci: makanan, kebiasaan cuci tangan, diare

\section{ABSTRACT}

Healthy food contains many nutrition substance that children need. But sometimes bacteria and poison contamination can cause diarrhea. Unprocedural hand washing habit can increase diarrhea. Aim of this study was to identify the relationship between food and hand washing habit with the incidence of diarrhea on early childhood at Tambak Wedi Administrative Village, Kenjeran Subdistric, Surabaya City. This research used correlation design with cross sectional approach. Samples of this research were 67 childern at five PAUD course at Tambak Wedi Administrative Village, Kenjeran Subdistric, Surabaya City. This research used simple random sampling. Data was collected by questionnaire. The result was tabulated and analized by coefficient contingency. The result showed there was a strong relationship between food and the incidence of diarrhea which $p$ value $0.000(\alpha \leq 0.05)$ and $r=$ 0.615 and there was a strong relationship between hand washing habit and the incidence of diarrhea which $p$ value $0.000(\alpha \leq 0.05)$ and $r=0.619$. It is expected that parents can provide $a$ healthy diet and proper hand washing habit at an early childhood in order to prevent the incidence of diarrhea.

Keywords: food, hand washing habit, diarrhea

\section{PENDAHULUAN}

Kebutuhan gizi pada manusia merupakan hal penting, terutama pada masa anak-anak. Gizi dapat diperoleh dari berbagai makanan yang dikonsumsi, baik berdasarkan jenis makanan, cara menyajikannya, dan cara mengkonsumsinya. Makanan yang sehat adalah makanan yang didalamnya terkandung zat-zat gizi. Akan tetapi makanan sehat tidak saja jenisnya melainkan cara penyajian dan cara mengkonsumsi harus sehat pula. Cara penyajian yang sehat harus pada kemasan tertutup rapat yang bebas dari lalat, nyamuk. Cara mengkonsumsi yang benar 
agar makanan tersebut tetap sehat adalah harus senantiasa memperhatikan kebersihan tangan melalui mencuci tangan sebelum makan. Makanan yang baik harus meliputi enam prinsip higiene yaitu keadaan bahan makanan haruslah dalam kondisi baik/ tidak busuk, cara menyimpan bahan-bahan makanan haruslah ditempat yang benar, cara pengolahan makanan haruslah benar, cara mengangkutan harus bebas dari kotoran atau serangga, cara menyimpan makanan haruslah ditempat yang tertutup, bersih dan cara penyajiannya harus memperhatikan kebersihan makanan serta kebersihan tangan sebelum mengonsumsinya. Banyak anak tidak terkecuali anak usia dini (PAUD) banyak yang senang mengkonsumsi makanan tanpa melihat kebersihan makanan, seperti makanan dalam kemasan yang tidak tertutup rapat, dihinggapi lalat. Tidak sedikit pula diantara mereka yang memiliki kesadaran mencuci tangan sebelum makan yang masih relatif kecil, karena keterbatasan kognitif dan menyesuaikan masa perkembangan mereka. Hal tersebut, mengakibatkan banyaknya timbul penyakit, tersering adalah diare.

Berdasarkan hasil penelitian Bimasesar dan Razif (2015) yang berjudul Perbandingan Kualitas Mikrobiologi Air Minum (Coliform) dengan Angka Penyakit Diare di Kelurahan Tambak Wedi Kecamatan Kenjeran Surabaya menunjukkan angka kejadian diare sangat tinggi dibandingkan kelurahan lainnya sebanyak $21 \%$.

Diare terbanyak disebabkan oleh faktor eksternal antara lain faktor sanitasi lingkungan, faktor ekonomi, faktor individu yaitu kebiasaan cuci tangan, rasa cemas dan takut. Diantara banyak faktor penyebab diare yang sering ditemukan adalah faktor makanan dan faktor kebiasaan mencuci tangan yang sering menjadi penyebab diare. Menurut Ngastiyah (2005), makanan merupakan penyebab non infeksi yang paling sering diantaranya: makanan busuk/ mengandung racun, perubahan susunan makan yang mendadak/terlalu banyak serat, alergi terhadap makanan tertentu dan makanan yang tercemar. Kebersihan makanan yang dikonsumsi dan kebersihan tangan sangatlah penting, kebersihan makanan dan kebersihan tangan anak sehari-hari juga perlu diperhatikan. Dua faktor tersebut merupakan faktor tersering penyebab terjadinya suatu penyakit infeksi saluran pencernaan yaitu diare. Diare bila tidak segera diatasi akan berakibat anak mengalami dehidrasi, disusul kerusakan mukosa usus, lemas, kejang, syok hipovolemik, bahkan terjadinya kematian.

Berbagai cara telah dilakukan oleh Dinas Kesehatan Kota (DKK) Surabaya untuk mengatasi dua faktor tersebut, yaitu menerapkan kebiasaan menjaga kebersihan tangan diantaranya dilakukan perlombaan mencuci tangan di berbagai wilayah sekolah. Selain itu DKK Surabaya juga menerapkan cara menjaga makanan agar tidak terkontaminasi diantaranya makanan harus lulus uji Badan Pengawas Obat dan Makanan (BPOM). Mengingat masih rendahnya kebiasaan mencuci tangan dan kontrol konsumsi makanan pada anak usia dini dan masih adanya makanan yang dipasarkan tanpa melalui lulus uji dari BPOM sehingga ibu harus selalu menerapkan selektif dalam memilih makanan dan untuk menambah kebersihan maka ibu bisa mengajarkan sejak dini tentang kebiasaan mencuci tangan sebelum dan sesudah makan. Alangkah baiknya jika kebiasaan mencuci tangan tidak hanya dilakukan sebelum atau sesudah makan tetapi juga setelah bermain, hendak masuk rumah, hendak tidur dan sebagainya. Cuci tangan secara konvensional yaitu menggunakan sabun terkadang membuat anak enggan, oleh sebab itu dengan adanya metode baru yaitu cuci tangan tanpa air (hand sanitizer), akan lebih menarik bagi anak karena sensasi fresh, dingin, wangi bahkan dikemas pada botol berbagai warna dan bentuk yang lucu.

Tujuan dari penelitian ini adalah mengidentifikasi hubungan makanan dan kebiasaan mencuci tangan dengan kejadian diare pada anak usia dini di Kelurahan Tambak Wedi Kecamatan Kenjeran Surabaya. 


\section{METODE PENELITIAN}

Penelitian dilakukan di beberapa PAUD di Kelurahan Tambak Wedi Kecamatan Kenjeran Surabaya dan dilaksanakan mulai 21 Maret 2016 sampai dengan 24 Juni 2016.

Desain yang digunakan dalam penelitian ini adalah kolerasi cross sectional. Populasi dalam penelitian ini: semua Ibu dari anak PAUD di Kelurahan Tambak Wedi Kecamatan Kenjeran Surabaya. Sampel dari penelitian ini adalah ibu dari anak PAUD di Kelurahan Tambak Wedi Kecamatan Kenjeran Surabaya yang hadir pada saat pengambilan data sejumlah 67 responden.

Teknik sampling menggunakan simple random sampling pada lima PAUD yang ada di Kelurahan Tambak Wedi yaitu PAUD Permata Hati, PAUD Suramadu, PAUD Pelangi, PAUD Alisia, PAUD The Alf.

Variabel dependen dalam penelitian ini adalah kejadian diare yaitu pengalaman yang diungkapkan oleh ibu dimana anak pernah mengalami peningkatan defekasi yang lebih dari 3 kali dalam 24 jam dengan konsistensi feses yang cair, berlendir atau tidak, warna feses kehijauan atau tidak, bahkan terdapat darah ataupun tidak dan perut terasa mulas. Variabel independen pertama dari penelitian ini adalah kebiasaan mencuci tangan yaitu ritual anak dalam menghilangkan kotoran yang menempel di kulit tangan dengan cara mengalirkan air, sabun dan mengeringkannya dengan frekuensi serta waktu tertentu. Variabel independen kedua adalah makanan yang masuk melalui mulut yang mempunyai kandungan gizi dan dikonsumsi dengan cara tertentu serta mencakup beberapa prinsip higiene meliputi karakteristik, pola, kontaminasi dan lokasi pembelian.

Dalam penelitian ini pengumpulan data dilakukan dengan mengunakan alat ukur kuesioner dengan jenis pertanyaan tertutup (close ended) dimana angket tersebut dibuat sedemikian rupa sehingga responden hanya tinggal memilih atau menjawab pada pertanyaan yang sudah ada.

Hasil penelitian ditabulasi dan persentasi, selanjutnya dianalisis dengan program SPSS 18 menggunakan uji statistik korelasi Koefisiensi Kontigensi dengan $\alpha<0,05$.

\section{HASIL DAN PEMBAHASAN}

Data Umum

TABEL 1 DISTRIBUSI FREKUENSI RESPONDEN

\begin{tabular}{|c|c|c|c|}
\hline No & Karakteristik & $\mathrm{n}$ & $\%$ \\
\hline \multirow[t]{3}{*}{1} & Umur anak & & \\
\hline & 2-3 tahun & 19 & 28.3 \\
\hline & 4-5 tahun & 48 & 71.7 \\
\hline \multirow[t]{5}{*}{2} & Umur orang tua & & \\
\hline & 20-25 tahun & 17 & 25.4 \\
\hline & 26-30 tahun & 21 & 31.3 \\
\hline & 31-35 tahun & 19 & 28.4 \\
\hline & 36-40 tahun & 10 & 14.9 \\
\hline \multirow[t]{5}{*}{3} & \multicolumn{3}{|c|}{ Pendidikan orang tua } \\
\hline & SD & 7 & 10.4 \\
\hline & SMP & 19 & 28.4 \\
\hline & SMA & 40 & 59.7 \\
\hline & PT & 1 & 1.5 \\
\hline \multirow[t]{4}{*}{4} & \multicolumn{3}{|c|}{ Pekerjaan Orang Tua } \\
\hline & Ibu rumah tangga & 56 & 83.5 \\
\hline & Swasta & 10 & 15 \\
\hline & PNS & 1 & 1.5 \\
\hline
\end{tabular}

Tabel 1 menunjukkan karakteristik responden berdasarkan umur anak sebagian besar adalah 4-5 tahun yaitu 48 responden (71.7\%), umur orang tua sebagian sebar 2630 tahun yaitu 21 responden (31.3), pendidikan orang tua sebagian besar adalah SMA yaitu 40 responden (59.7\%), berdasarkan pekerjaan orang tua sebagian besar adalah ibu rumah tangga yaitu 56 responden $(83.5 \%)$

\section{Data Khusus}

Tabel 2. Tabulasi silang variabel makanan dan kejadian diare

\begin{tabular}{|c|c|c|c|c|c|c|}
\hline \multirow{4}{*}{ No } & \multirow{3}{*}{ Variabel } & \multicolumn{4}{|c|}{ Kejadian diare } & \multirow{3}{*}{ Total } \\
\hline & & \multicolumn{2}{|c|}{ IYA } & \multicolumn{2}{|c|}{ TIDAK } & \\
\hline & & $\mathrm{n}$ & $\%$ & $\mathrm{n}$ & $\%$ & \\
\hline & Makanan & & & & & \\
\hline 1 & Sehat & 4 & 6 & 18 & 27 & 22 \\
\hline \multirow[t]{2}{*}{2} & Tidak sehat & 42 & 63 & 3 & 4 & 45 \\
\hline & Total & 46 & 69 & 21 & 31 & 67 \\
\hline
\end{tabular}

Uji Koefisien Kontigensi $p$ value $=0.000(\alpha<0.05)$

Berdasarkan tabel 2 anak yang mengkonsumsi makanan tidak sehat dan 
mengalami diare adalah 42 anak (63\%) dari 67 responden.

Tabel 3. Tabulasi silang variabel kebiasaan cuci tangan dan kejadian diare

\begin{tabular}{|c|c|c|c|c|c|c|}
\hline \multirow{3}{*}{ No } & \multirow{3}{*}{ Variabel } & \multicolumn{4}{|c|}{ Kejadian diare } & \multirow{3}{*}{ Total } \\
\hline & & \multicolumn{2}{|c|}{ IYA } & \multicolumn{2}{|c|}{ TIDAK } & \\
\hline & & $\mathrm{n}$ & $\%$ & $\mathrm{n}$ & $\%$ & \\
\hline & Mencuci tan & & & & & \\
\hline 1 & Benar & 2 & 3 & 17 & 26 & 19 \\
\hline \multirow[t]{2}{*}{2} & Tidak benar & 44 & 65 & 4 & 6 & 44 \\
\hline & Total & 46 & 68 & 21 & 32 & 67 \\
\hline
\end{tabular}

Berdasarkan tabel 3 anak yang tidak melakukan cuci tangan dengan benar dan mengalami diare adalah 44 anak (65\%) dari 67 responden.

\section{PEMBAHASAN}

Berdasarkan hasil penelitian dari 67 sampel responden menunjukkan terdapat hubungan antara makanan dan kebiasaan cuci tangan terhadap kejadian diare di PAUD Kelurahan Tambak Wedi Kecamatan Kenjeran Surabaya, yang meliputi sebagian besar responden mengonsumsi makanan tidak sehat sebanyak 45 responden (67\%). Sebagian besar responden yang cuci tangan tidak benar sebanyak 48 responden (71\%). Sebagian besar responden yang mengalami diare sebanyak 46 responden $(69 \%)$. Sebagian besar responden yang mengonsumsi makanan tidak sehat dan mengalami diare sebanyak 42 responden (63\%). Sebagian besar responden yang cuci tangan tidak benar dan mengalami diare sebanyak 44 responden $(65 \%)$.

\section{Hubungan makanan dengan kejadian diare.}

Berdasarkan tabel 2 dari penelitian didapatkan responden yang mengonsumsi makanan tidak sehat sebanyak 45 responden (67\%). Hasil penelitian didapatkan sebagian besar responden mengalami kejadian diare karena makanan yang tidak sehat sebanyak 42 responden (63 $\%$ ). Setelah dilakukan uji "koefisiensi kontigensi" diperoleh sig (taraf signifikan) $\mathrm{p}$ value $=0.00 \geq 0.05$ artinya probability value atau nilai uji kurang dari 5\% yang menunjukkan kesalahan yang dibuat peneliti kurang dari 5\% ini membuktikan bahwa $\mathrm{H} 0$ ditolak sedangkan $\mathrm{H} 1$ diterima yang artinya terdapat hubungan makanan terhadap diare di PAUD kelurahan tambak wedi kecamatan kenjeran surabaya. Dengan nilai correlation coefficient $=0,605$ yang diasumsikan adanya hubungan yang kuat antara makanan dengan kejadian diare di PAUD Kelurahan Tambak Wedi Kecamatan Kenjeran Surabaya. Menurut Ngastiyah (2005), makanan merupakan penyebab non infeksi yang paling sering. Makanan tidak sehat merupakan makanan yang sudah terkontaminasi oleh zat luar yang mengurangi nilai gizi dari makanan tersebut dan bahkan berbahaya bagi kesehatan yang memakan makanan tersebut. Misalnya makanan yang dihinggapi lalat yang sering kali menyebabkan seseorang yang mengonsumsi makanan tersebut mengalami diare. Maka menurut peneliti, bahwasannya antara fakta dan teori tentang makanan dengan kejadian diare yang didapatkan berkaitan. Makanan masuk melalui mulut akan menuju saluran cerna, jika makanan yang dikonsumsi tidak sehat maka akan menganggu proses saluran cerna, selain itu makanan yang tidak dicerna dan tidak dapat diserap usus akan menarik air dari dinding usus. Maka, perpindahan air dari usus menjadi sangat singkat sehingga air tidak sempat diserap oleh usus besar. Hal ini yang menyebabkan diare. Manusia tidak lepas dari makanan untuk mempertahankan hidupnya. Banyak manusia mengonsumsi makanan tanpa memperhatikan tingkat kesehatan. Makanan yang disukai manusia pada umumnya disukai oleh mikroorganisme seperti virus, bakteri, dan jamur. Maka menurut peneliti, bahwasannya antara fakta dan teori tentang makanan yang didapatkan berkaitan. Adapun beberapa faktor yang membuat makanan menjadi tidak sehat diantaranya cara penyajian yang tidak sehat yaitu pada kemasan yang tidak tertutup rapat dan dihinggapi lalat lalat, nyamuk dan lingkungan pada saat mengonsumsi juga mempengaruhi makanan tersebut. Di lingkungan PAUD terdapat banyak 
pedagang yang berjualan makanan yang tidak sehat di antara gorengan yang tidak tertutup rapat, sosis, makanan ringan, dll yang berbahaya bagi kesehatan pencernaan anak. Oleh karena itu alangkah lebih baik jika ibu mengupayakan menyediakan bekal sekolah bagi anak sehingga keinginan untuk jajan jauh berkurang dan secara tidak langsung dapat mengurangi kontaminasi bakteri maupun racun yang terdapat pada makanan yang tidak sehat tersebut pada anak, dan mengurangi kejadian diare pada anak.

\section{Hubungan kebiasan mencuci tangan dengan kejadian diare.}

Berdasarkan tabel 3 dari penelitian di dapatkan cuci tangan tidak benar sebanyak 48 responden $(71 \%)$. Berdasarkan tabel 3 dari penelitian didapatkan kejadian diare yaitu sebanyak 46 responden (69\%). Hasil menunjukkan sebagian besar responden mengalami pengalaman diare karena tidak mencuci tangan dengan benar sebanyak 44 responden $(65 \%)$. Setelah dilakukan uji "koefisiensi kontigensi" diperoleh sig (taraf signifikan) $p$ value $=0.00 \geq 0.05 \mathrm{ini}$ membuktikan bahwa H0 ditolak sedangkan $\mathrm{H} 1$ diterima yang artinya terdapat hubungan kebiasaan mencuci tangan terhadap diare di PAUD kelurahan tambak wedi kecamatan kenjeran surabaya. Dengan nilai correlation coefficient $=0,619$ yang diasumsikan adanya hubungan yang signifikan antara hubungan kebiasaan mencuci tangan terhadap diare di PAUD Kelurahan Tambak Wedi Kecamatan Kenjeran Surabaya. Menurut Ngastiyah (2005), beberapa faktor yang mempengaruhi diare yaitu faktor infeksi kuman, faktor makanan, faktor gizi, dan faktor sosial ekonomi. Maka menurut peneliti, bahwasannya antara fakta dan teori tentang menjaga kebersihan selama anak berinteraksi memang sangat erat kaitannya dengan kejadian diare. Tangan yang kotor menyebabkan perpindahan antara kuman dari tangan ke saluran pencernaan sehingga menyebabkan anak menjadi diare. Mencuci tangan adalah membersihkan segala macam kuman yang menyebabkan segala macam penyakit, anak harus membiasakan mencuci tangan. Selain itu mencuci tangan juga harus dengan benar yaitu dengan air mengalir, sabun dan juga mengeringkan dengan tisu. Tangan yang bersih adalah salah satu upaya untuk mencegah penyebaran penyakit, penyakit yang disebarkan melalui tangan diantaranya adalah diare. Kebiasaan cuci tangan dengan kejadian diare yang didapatkan berkaitan. Kebersihan tangan juga menentukan kesehatan anak. Oleh sebab itu sejak dini orang tua diharapkan bisa membiasakan mencuci tangan. Peran ibu yang besar dalam mendidik anak mencuci tangan yang disertai dengan ilustrasi apa yang mungkin terjadi apabila seseorang tidak melakukan cuci tangan seperti sakit diare (Wong, 2003). Adanya pembelajaran cara mencuci tangan dengan baik dapat berdampak pada kejadian diare pada anak lebih sedikit dibanding dengan yang terkena diare. Cuci tangan yang benar bisa dengan mengikuti enam langkah WHO.

\section{SIMPULAN}

Terdapat hubungan kuat antara makanan dan kebiasaan cuci tangan dengan kejadian diare di PAUD Kelurahan Tambak Wedi Kecamatan Kenjeran Surabaya. Makanan yang sehat dan higienis disertai dengan kebiasaan cuci tangan dengan benar dapat mengurangi kejadian diare.

\section{SARAN}

1. Diharapkan orang tua mengajarkan tehnik mencuci tangan yang benar. Orang tua menyediakan bekal untuk anak supaya lebih higienis dan kandungan gizi tetap terjaga.

2. Diharapkan peran serta pengajar PAUD, kader maupun petugas Puskesmas dapat memberikan atau mengajarkan cuci tangan yang benar dan memberikan penyuluhan tentang makanan sehat dan higienis.

\section{DAFTAR PUSTAKA}

1. Hidayat, A. Alimul. 2009. Pengantar Ilmu keperawatan Anak. Jakarta: Salemba Medika. 
2. Wong, L.,D. 2003. Pedoman Klinis Perawatan Pediatrik Edisi Buku Kedokteran. Jakarta: EGC.

3. Notoatmodjo, S. 2003. Pendidikan dan Perilaku Kesehatan. Jakarta: Rineka Cipta.

4. Ngastiyah. 2005. Perawatan Anak Sakit. Jakarta: EGC.

5. Suriadi. 2001. Asuhan Keperawatan Pada Anak. Jakarta: PT Fajar Interpratama.

6. Bimasesar, T.K \& Razif, M. 2015. Perbandingan Kualitas Mikrobiologi
Air Minum (Coliform) dengan Angka Penyakit Diare di Kelurahan Tambak Wedi Kecamatan Kenjeran Surabaya. Skripsi ITS Digilib. Diakses pada tanggal 02 Pebruari 2015 pukul 12.00 WIB.

7. Suradi \& Yuliani, R. 2006. Asuhan Keperawatan pada Anak. Jakarta: Sagung Seto.

8. Nursalam M, dkk. 2005. Asuhan Keperawatan Bayi dan Anak. Ed : 1. Jakarta: Salemba Medika. 